\title{
Acute coronary syndrome caused by compression of the left main coronary artery - the usefulness of computed tomography in diagnosis and interventional treatment planning
}

Ostry zespół wieńcowy spowodowany kompresją pnia lewej tętnicy wieńcowej - przydatność tomografii komputerowej w rozpoznaniu i planowaniu leczenia interwencyjnego

\author{
Cezary Kępka ${ }^{1}$, Zofia Dzielińska ${ }^{1}$, Adam Torbicki ${ }^{2}$ Marcin Kurzyna ${ }^{2}$, Zbigniew Chmielak ${ }^{3}$, Radosław Pracońn ${ }^{1}$, \\ Michał Florczyk², Maria Wieteska'2, Jerzy Pręgowski ${ }^{3}$, Mariusz Kruk', Marcin Demkow ${ }^{1}$ \\ 1Department of Coronary and Structural Heart Diseases, Institute of Cardiology, Warsaw, Poland \\ 2Europejskie Centrum Zdrowia, Otwock, Poland \\ 3Department of Interventional Cardiology and Angiology, Institute of Cardiology, Warsaw, Poland
}

Post Kardiol Interw 2012; 8, 1 (27): 61-65 DOI: $10.5114 /$ pwki.2012.27928

\begin{abstract}
This case presents a 46-year-old female patient with advanced pulmonary hypertension referred to our center due to typical symptoms of acute coronary syndrome. Coronary computed tomography angiography revealed severe stenosis of the left main coronary artery caused by compression of the artery by the dilated main pulmonary artery. A good quality computed tomography study enabled precise planning of surgery and was more useful than invasive coronary angiography.
\end{abstract}

Key words: coronary computed tomography, left main compression, acute coronary syndrome

\section{Streszczenie}

Przedstawiamy przypadek 46-letniej pacjentki z zaawansowanym nadciśnieniem płucnym skierowanej do naszego ośrodka z typowymi objawami ostrego zespołu wieńcowego. Dzięki wykonaniu badania metodą tomografii komputerowej tętnic wieńcowych możliwe było rozpoznanie ciasnego zwężenia pnia lewej tętnicy wieńcowej spowodowanego jego kompresją przez poszerzony pień płucny. Badanie tomografii komputerowej dobrej jakości umożliwiło precyzyjne zaplanowanie zabiegu i okazało się bardziej przydatne niż koronarografia inwazyjna.

Słowa kluczowe: tomografia komputerowa, kompresja pnia lewej tętnicy wieńcowej, ostry zespół wieńcowy

\section{Case report}

A 46-year-old female patient with severe idiopathic pulmonary hypertension treated with sildenafil and a prostacyclin analogue in NYHA class III/IV was transferred to the Institute of Cardiology because of anginal pains. Crescendo angina had begun a few weeks before the hospitalization and in the recent period had taken the form of recurrent resting pains. Electrocardiogram showed right bundle branch block with oscillating myocardial ischaemia during angina.
Echocardiographic examination confirmed the presence of pulmonary hypertension with aneurysmal dilation of the pulmonary trunk (maximal diameter of $44 \mathrm{~mm}$ ) and a dilated, hypokinetic right ventricle. Left ventricular contractility and volume were assessed as normal. Laboratory examinations demonstrated an increased troponin level. Because of the patient's clinical instability an emergency computed tomography $(\mathrm{CT})$ of the coronary arteries was performed.

Corresponding author/Adres do korespondencji:

Cezary Kępka MD, PhD, Department of Coronary and Structural Heart Diseases, Institute of Cardiology, 42 Alpejska, 04-628 Warsaw, Poland, e-mail: ckepka@ikard.pl

Praca wpłynęła: 15.12.2011, przyjęta do druku: 30.01.2012. 


\section{Diagnostic imaging and treatment planning}

The study was performed using a 128 slice dual source scanner (Somatom Definition Flash - Siemens, Germany) and an acquisition protocol optimized for the assessment of coronary arteries. Because of the fast resting heart rate (82 bpm) a protocol with retrospective ECG gating was used. Scan time was $4.8 \mathrm{~s}$ and $60 \mathrm{ml}$ of a high-iodine concentration contrast agent (Iomeron 400 - Bracco, Italy) was administered. Total radiation dose of the study was $6.2 \mathrm{mSv}$.
Computed tomography excluded the presence of coronary anomalies and atherosclerotic plaques in coronary arteries, but showed a critical stenosis of the ostium of the left main coronary artery (LMCA) caused by compression from the aneurysmally dilated pulmonary trunk (Figure 1 A-F). Minimal lumen area of the left main coronary artery was less than $3.0 \mathrm{~mm}^{2}$.

Because of the unstable clinical condition, after detailed assessment of the anatomical relations shown in com-
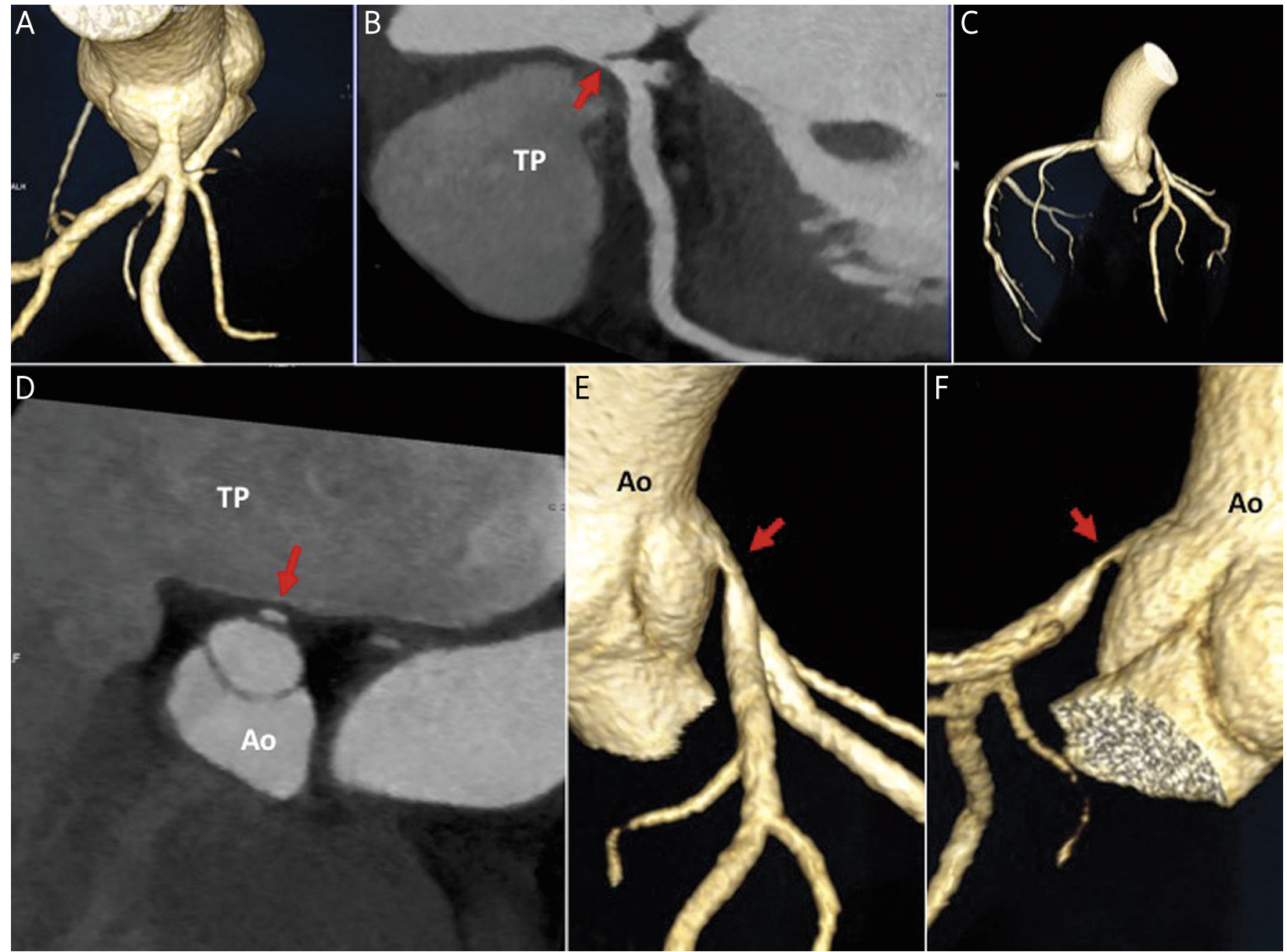

Fig. 1. Computed tomography of the coronary arteries: A - volume reconstruction (VRT) showing the left main coronary artery (LMCA) originating normally from the left coronary sinus and dividing into two vessels; B - MIP presentation, a tight left main coronary artery stenosis is seen (arrow) caused by compression from a giant pulmonary trunk; C - VRT reconstructions - a picture of the whole vessel tree, no anomalies or atherosclerotic changes; D - MIP transverse view at the level of a proximal LMCA segment - confirmation of the significant LMCA compression (arrow); E, F - VRT reconstruction of the LMCA in various views allowing detailed assessment of the anatomical conditions

Ao-aorta, TP-pulmonary artery

Ryc. 1. Tomografia komputerowa tętnic wieńcowych: $A$ - rekonstrukcja objętościowa (VRT) - widoczny prawidtowo odchodzacy od lewej zatoki wieńcowej pień lewej tętnicy wieńcowej (LTW), dzielacy się na dwa naczynia; $B$ - prezentacja MIP, widoczne ciasne zwężenie światła pnia LTW (strzałka) spowodowane kompresja przez olbrzymi pień płucny; $C$ - rekonstrukcje VRT - obraz całego drzewa naczyniowego, brak anomalii i zmian miażdżycowych; D - prezentacja MIP - przekrój poprzeczny przez początkowy odcinek pnia LTW - potwierdzona istotna kompresja pnia LTW (strzatka); E, F-rekonstrukcje VRT LTW w różnych projekcjach umożliwiające dokładna ocenę stosunków anatomicznych

Ao - aorta, TP - tętnica płucna 
puted tomography, the patient was offered treatment by means of a percutaneous coronary intervention.

Computed tomograhy allowed a precise assessment of the anatomical conditions and therefore permitted planning of the percutaneous coronary intervention. MPR, CMPR and VRT reconstruction images were used to assess the length of the LMCA, the length of stenosis and the reference diameter of the vessel (Figure $2 \mathrm{~A}-\mathrm{D}$ ). Precise assessment of the lesion length was also possible by means of transverse views similar to those obtained with intravascular ultrasound (Figure 2 A-D). Image analysis permitted planning of the procedure consisting of stent implantation to the proximal LMCA segment without the need of bifurcation involvement.

After signing informed written consent the patient received dual antiplatelet therapy and was prepared for the procedure.

\section{Percutaneous coronary intervention}

Left main coronary artery stenosis was not seen in the few initial, typical left coronary artery views (Figure $3 \mathrm{~A}-\mathrm{C}$ ). Additional, atypical views planned according to the CT scan were necessary to demonstrate the compression of the left main ostium (Figure 4 A-B). It was impossible to find a view showing the ostium and the bifurcation of the left main coronary artery at the same time. Therefore precise planning of the stent length based solely on coronary angiography might have been inaccurate. Finally, based on the CT measurements, a stent of $4.0 \mathrm{~mm}$ diameter and $12 \mathrm{~mm}$ length was chosen (Figure $4 \mathrm{C}$ ). Optimal stent length was confirmed in two views (Figures 4 C, 5 A). The stent was post-dilated with a short $(10 \mathrm{~mm})$ high-pressure (non-compliant) balloon to reach the reference diameter of the vessel assessed by CT (Figure 5 B). A very

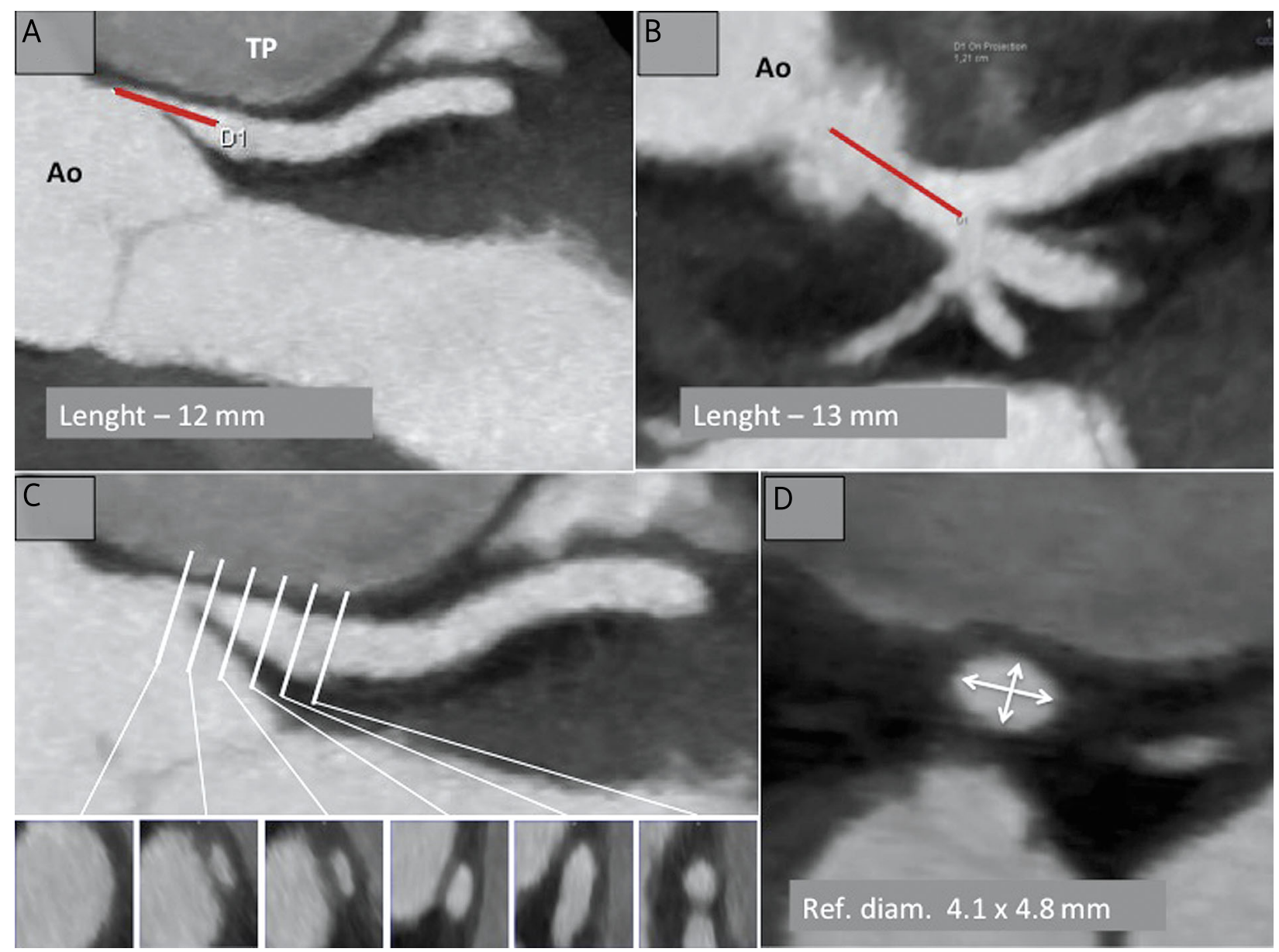

Fig. 2. Computed tomography of the coronary arteries, MIP presentation: A-B - views allowing precise planning of the stent length; $C$ - serial images in transverse views similar to the images from intravascular ultrasound; $D$ - transverse projection - measurement of reference diameter of the vessel - planning of the stent diameter Ao-aorta, TP-pulmonary artery

Ryc. 2. Tomografia komputerowa tętnic wieńcowych, prezentacja MIP: A-B - projekcje umożliwiające precyzyjne zaplanowanie długości stentu; $C$ - seryjne obrazy w przekrojach poprzecznych zbliżone do obrazu w badaniach echa wewnątrznaczyniowego; D - przekrój poprzeczny - pomiar średnicy referencyjnej naczynia, planowanie średnicy stentu

Ao-aorta, TP - tętnica płucna 

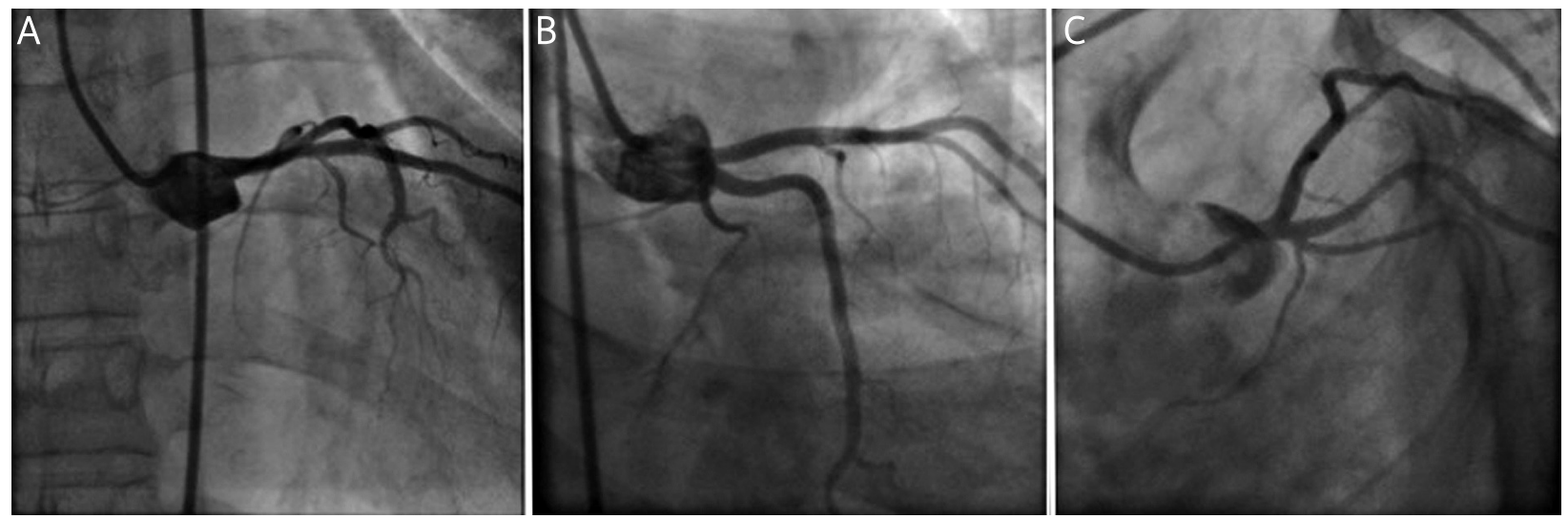

Fig. 3. Angiography of the left coronary artery: A-C - three typical views do not show the significant ostial LMCA stenosis

Ryc. 3. Koronarografia lewej tętnicy wieńcowej: $A-C$ - trzy typowe projekcje niepokazujące istotnego zwężenia w ujściu pnia LTW
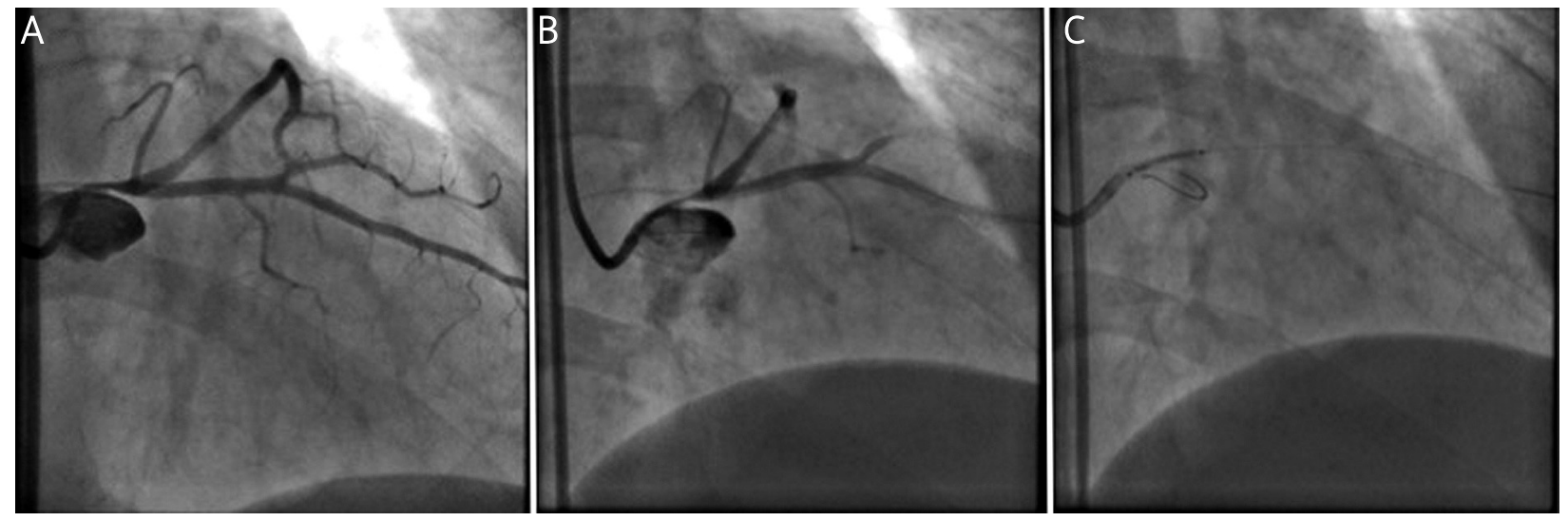

Fig. 4. Angiography of the left coronary artery: A-B - additional views elucidate a tight stenosis described before in computed tomography; $\mathbf{C}$ - positioning of the stent whose diameter and length were adjusted according to the computed tomography; one of the guidewires is placed in the left anterior descending artery and the second one in the left coronary sinus

Ryc. 4. Koronarografia lewej tętnicy wieńcowej: $A-B$ - dodatkowe projekcje ujawniają ciasne zwężenie, opisane wcześniej w badaniu metodą tomografii komputerowej; C - pozycjonowanie stentu o średnicy i długości dobranej na podstawie badania metoda tomografii komputerowej, jeden z prowadników wprowadzony do gatęzi przedniej zstępującej, drugi znajduje się w lewej zatoce wieńcowej

good angiographic effect of the procedure was obtained (Figure 5 C).

No complications of the procedure were observed. There were no anginal pains in the days following the procedure. Slow normalization of the myocardial necrotic markers was noted.

\section{Discussion}

The described case emphasizes the key role of noninvasive imaging by means of computed tomography in reaching a diagnosis and treatment planning in a patient with atypical pathology. It is probably the first in Poland and one of the few described cases where CT allowed a fast, safe and accurate diagnosis of an external compression of the left main coronary artery by a markedly dilated pulmonary trunk [1-3]. An indisputable advantage of $\mathrm{CT}$ is its possibility to assess anatomical structures beyond assessment of the coronary artery lumen. Data obtained during the CT scan are used for construction of two- or three-dimensional reconstructions which in the present case permitted us to form a definitive diagnosis and to plan an optimal method of treatment. In contrast to classic coronary angiography, CT scan does not have limitations which could in some cases exclude the possibility 

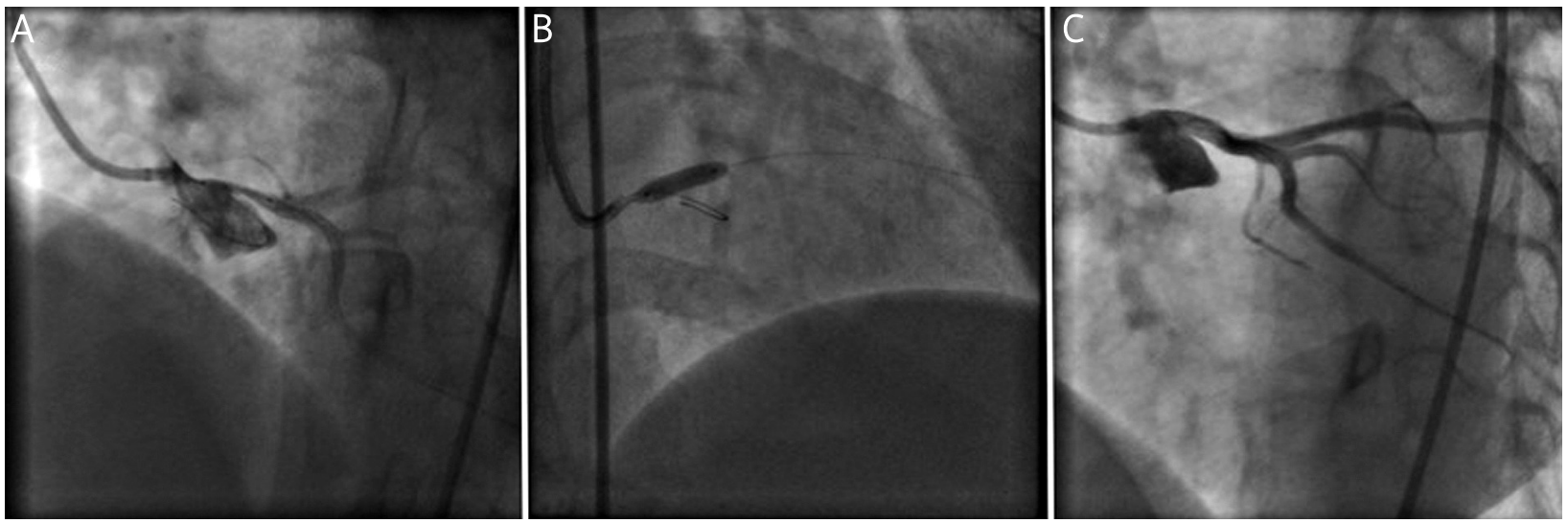

Fig. 5. Angiography of the left coronary artery: A - confirmation of the correct stent length; B - stent expansion under $20 \mathrm{~atm} ; \mathrm{C}-$ final effect of the procedure

Ryc. 5. Koronarografia lewej tętnicy wieńcowej: $\boldsymbol{A}$ - potwierdzenie właściwej długości stentu; $B$ - rozprężenie stentu ciśnieniem $20 \mathrm{~atm}$; C - finalny efekt zabiegu

of a reliable assessment of the vessel length and its reference diameter.

The knowledge about the angiographic picture of the patient before her arrival in the catheterization laboratory permitted us to:

1) choose the optimal treatment method (in the present case cardiac surgery was denied due to high risk),

2) collect the informed consent in a comfortable way for the patient,

3) initiate pre-procedural pharmacotherapy, and

4) prepare for the percutaneous procedure (choose a guiding catheter or the right stent in terms of its diameter, length and maximal radial force).

Information based on the good quality images from computed tomography are useful in planning of the interventional and surgical revascularization, not only in the present case, but also in patients with atherosclerotic changes $[4,5]$. Computed tomography data have similar quality to coronary angiography supplemented by intravascular ultrasound. In the present case, information about the results of the CT scan was known to the treating physician and to the interventional cardiologist and therefore permitted correct treatment planning and safe conduction of the procedure.

\section{References}

1. Dodd JD, Maree A, Palacios I, et al. Left main coronary artery compression syndrome evaluation with 64-slice cardiac multidetector computed tomography. Circulation 2007; 115: e7-e8.

2. Bonderman D, Fleischmann D, Prokop M, et al. Left main coronary artery compression by the pulmonary trunk in pulmonary hypertension. Circulation 2002; 105: 265.

3. Safi M, Eslami V, Shabestari AA, et al. Extrinsic compression of left main coronary artery by the pulmonary trunk secondary to pulmonary hypertension documented using 64-slice multidetector computed tomography coronary angiography. Clin Cardiol 2009; 32: 426-428.

4. Pregowski J, Kepka C, Kruk M, et al. Comparison of usefulness of percutaneous coronary intervention guided by angiography plus computed tomography versus angiography alone using intravascular ultrasound end points. Am J Cardiol 2011; 108: 1728-1734.

5. Kepka C, Opolski MP, Juraszynski Z, et al. Computed tomography to predict surgical revascularization of a left anterior descending artery occlusion incompletely visualized by conventional angiography. J Thorac Imaging 2011 Jul 26. [Epub ahead of print] PubMed PMID: 21795996. 